\title{
Research on the Joint Ventures between Algeria and China in Car Manufacturing
}

\author{
Ahmed Dekkar ${ }^{1}$, Dr. Yang Qing ${ }^{2}$ \\ ${ }^{1}$ (Department of Management Science, Wuhan University of Technology P. R. China) \\ 2 (Department of Economics \& Management of Technology, Wuhan University of Technology P. R. China)
}

\begin{abstract}
International Joint Ventures "IJVs" have certainly emerged as a compelling strategic option for companies because it has the best offset of return/risk. Unfortunately, IJV performance \& survival remains highly variable. Researchers have suggested that motives of establishing IJVs, performance assessment methods, and partner selection influence IJVs performance \& survival. However, we understand little about how these factors relate to one another to affect IJVs performance \& survival. Thus, this article takes an early step toward filling this gap by analyzing the potential IJV between Algeria \& China in car manufacturing. The study findings revealed that there are disparities in the motives of establishing the venture. Nonetheless, it would be able to achieve each partner motives. Concerning choosing the suitable partner, there is somewhat complementary-resources between the two partners. Moreover, the study revealed a discrepancy in performance assessment methods, in which the Algerian partner focuses on financial return, and the Chinese partner on the achievement of the venture motives.
\end{abstract}

Keywords Algeria Car Market, Chinese Car Manufacturers, IJV Formation Motives, IJV Partner Selection, IJV Performance Assessment

\section{Introduction}

Since 2008, China has become the largest automotive industry in the world measured by its automobile unit production. According to China Association of Automobile Manufacturers (CAAM), China's total vehicle production for the year 2012 reached 15.52 million. Out of this huge number of cars made in China, nearly $45 \%$ were local brands (BYD, Brilliance Automobile, Geely Automobile, Chery Automobile, Great Wall, etc) and the rest of it has being produced through joint ventures between local \& foreign car manufacturers.

Most of the cars manufactured in China are sold within its market, hence, it sparks a fierce competition between local car manufacturers, therefore they are always looking for international expansion (go abroad) to reach dynamic markets (like Africa, Latin America, and Asia), meanwhile improving their products quality to reach mature markets like USA, EU, and Japan. Yet, even though the Chinese cars are sold in many countries across the world but the Chinese local car brands exports are still modest. Table 1 shows the Top Five Export Markets of Chinese Automobiles for the last five years (2008-2012)

Table 1 Top Five Export Markets of Chinese Automobiles from 2008 to 2012

\begin{tabular}{|c|c|c|c|c|c|c|c|c|c|c|c|c|c|c|}
\hline Year & \multicolumn{2}{|c|}{2008} & Year & \multicolumn{2}{|c|}{2009} & Year & \multicolumn{2}{|c|}{2010} & Year & \multicolumn{2}{|c|}{2011} & Year & \multicolumn{2}{|c|}{2012} \\
\hline $\begin{array}{c}\text { Annual } \\
\text { Total } \\
\text { Auto } \\
\text { Exports }\end{array}$ & $100 \%$ & $\begin{array}{c}681,00 \\
8 \\
\text { Units }\end{array}$ & $\begin{array}{c}\text { Annual } \\
\text { Total } \\
\text { Auto } \\
\text { Exports }\end{array}$ & $\begin{array}{c}100 \\
\%\end{array}$ & $\begin{array}{c}370,0 \\
30 \\
\text { Units }\end{array}$ & $\begin{array}{c}\text { Annual } \\
\text { Total } \\
\text { Auto } \\
\text { Exports }\end{array}$ & $\begin{array}{c}100 \\
\%\end{array}$ & $\begin{array}{c}566,65 \\
3 \\
\text { Units }\end{array}$ & $\begin{array}{c}\text { Annual } \\
\text { Total } \\
\text { Auto } \\
\text { Exports }\end{array}$ & $100 \%$ & $\begin{array}{c}849,500 \\
\text { Units }\end{array}$ & $\begin{array}{c}\text { Annual } \\
\text { Total } \\
\text { Auto } \\
\text { Exports }\end{array}$ & $100 \%$ & $\begin{array}{c}1,056,09 \\
1 \\
\text { Units }\end{array}$ \\
\hline Russia & $\% 12.51$ & 85,241 & Algeria & $\begin{array}{c}\% 11 . \\
19\end{array}$ & $\begin{array}{c}41,40 \\
7\end{array}$ & Algeria & $\begin{array}{c}\% 8.3 \\
3\end{array}$ & 47,237 & Brazil & $\begin{array}{c}\% 12,2 \\
6\end{array}$ & 104,200 & Algeria & $\% 14,18$ & 149,800 \\
\hline Vietnam & $\% 7.76$ & 52,851 & Vietnam & $\begin{array}{c}\% 8.3 \\
0\end{array}$ & $\begin{array}{c}30,73 \\
2\end{array}$ & Syria & $\begin{array}{c}\% 5.7 \\
8\end{array}$ & 32,803 & Algeria & $\% 9,69$ & 82,400 & Iraq & $\% 8,53$ & 90,100 \\
\hline Algeria & $\% 6.59$ & 44,946 & Syria & $\begin{array}{c}\% 6.7 \\
9\end{array}$ & $\begin{array}{c}25,15 \\
7\end{array}$ & Vietnam & $\begin{array}{c}\% 5.5 \\
3\end{array}$ & 31,347 & Russia & $\% 8,4$ & 71,400 & Russia & $\% 8,49$ & 89,700 \\
\hline Iran & $\% 5.03$ & 34,253 & Egypt & $\begin{array}{c}\% 6.0 \\
3\end{array}$ & $\begin{array}{c}22,33 \\
6\end{array}$ & Russia & $\% 5.5$ & 31,209 & Chile & $\% 6,29$ & 53,500 & Iran & $\% 7,36$ & 77,800 \\
\hline Syria & $\% 4.73$ & 32,267 & Iran & $\begin{array}{c}\% 3.7 \\
6\end{array}$ & $\begin{array}{c}13,93 \\
1\end{array}$ & Chile & $\% 5.4$ & 30,642 & Iran & $\% 5,54$ & 47,100 & Chile & $\% 5,93$ & 62,700 \\
\hline
\end{tabular}

Source http://chinaautoweb.com/

As you can deduct from Table 1, Algeria has always been among the top five export markets for Chinese local car brands, moreover Algeria was the largest export market for three years, two years in a row 2009 and 2010, and in 2012.

During the year 2009, China exported 41, 407 units toward Algeria which represents roughly 11, $2 \%$ of China annual total auto exports. And during the year 2010, China exported 47, 237 units toward Algeria which represents roughly $8,3 \%$ of China annual total auto exports 
Finally, during the year 2012, Chinese car exports toward Algeria skyrocketed to reach the highest ever of 149, 800 units which makes up roughly $14,2 \%$ of China annual total auto exports

Therefore, Algeria which is one of the comparatively developed countries in North Africa, with car sales volume reaching almost 600,000 units per year, the second largest car market in Africa, is very interesting target for Chinese car manufacturers.

The Table 2 \& Figure 1 show Algeria Annual Total Auto Imports from the year 2007 to 2012

Table 2 Algeria Annual Total Auto Imports 2007-2012

\begin{tabular}{|c|c|c|c|c|c|c|}
\hline Year & 2007 & 2008 & 2009 & 2010 & 2011 & 2012 \\
\hline $\begin{array}{c}\text { Algeria Annual Total Auto } \\
\text { Imports "Unit" }\end{array}$ & 235,795 & 352,315 & 277,881 & 285,337 & 390,140 & 568,610 \\
\hline
\end{tabular}

Source http://www.ons.dz/

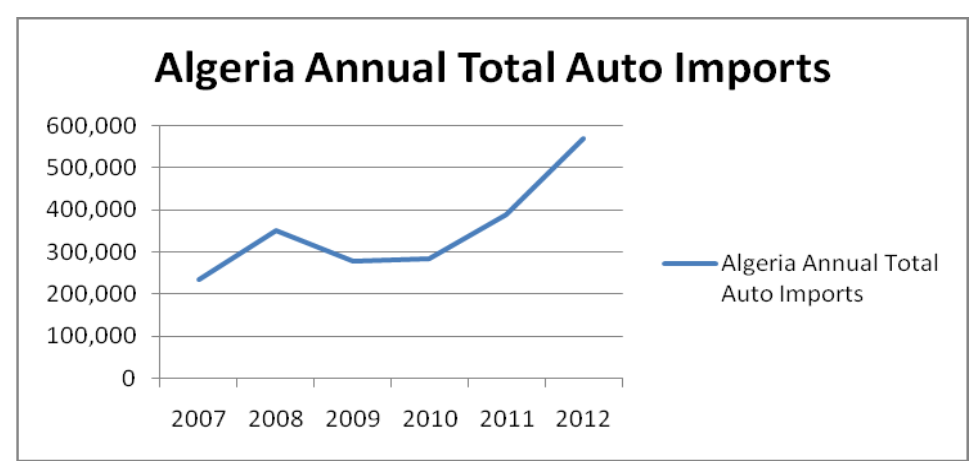

Figure 1 Algeria Annual Total Auto Imports 2007-2012

As you can deduct from Table 2 \& Fig 1, the Algerian car market is growing with an exponential rate. During the year 2007 Algeria imported 235,795 units, in 2008 the car imports increased by 50\% comparing to 2007 to reach 352,315 . But during the year 2009 , car imports dropped by $21 \%$ comparing to 2008 due to the world financial crisis and the ban of consumer credits by the Algeria government as a measure to tackle the financial crisis

In 2010 , car exports increased by $2,5 \%$ comparing to 2009 . But in 2011 , car imports increased by $36,8 \%$ and it continued in the same trend during the year 2012 to reach 568,610 units which represents an increased by 45 , $7 \%$ comparing to the previous year

The statistics show that the Algerian car market is growing very fast, and if it continues in the same trend, in the near future Algeria will topple South Africa to become Africa's largest car market.

Therefore the attractiveness of the Algerian car market prompts a slew of foreign car manufacturers to establish local production plants in Algeria, and taking initial steps toward auto production localization. Yet, doing business outside the home country is quite different from doing business in the international scale. Therefore, when investing in foreign countries, you should take on consideration a lot of factors that could lead to the failure. Thus, the statistics show that International Joint Ventures (IJVs) is taken the lion share from the Foreign Direct Investment (FDI) across the world.

IJV has emerged as a compelling strategic option for companies because it has the best offset of return/risk. Unfortunately, IJV performance and survival remains highly variable. Researchers stated that motives of establishing an IJV, partner selection, and performance assessment influence IJV performance and survival. However, we understand little about how these factors relate to one another to affect IJVs performance and survival. Thus, this article takes an early step towards filling this gap by analyzing the potential IJV between Algeria trucks Manufacturer Company (SNVI Entreprise Nationale des Véhicules Industriels) and five of the fast growing Chinese car manufacturers according to the annual sales growth \& patents "Chery Automobile, Great Wall Motor, Brillance Automobile, Geely Automobile, BYD”

\section{Literature Review}

The growth of strategic alliance during the period of growth has been monumental but, given the period of economic downturn which started in 2007 and is continuing throughout the year 2013. Strategic alliances are likely to grow even faster, the statistics show that joint ventures are taking the lion share from the other forms of strategic alliances in the world

Even though, IJV is very profitable for both business partners because of its high return and low risk, but IJV has a high variable performance (Pan \& Chi 1999), some succeed (Shenkar \& Nyaw 1994) while others failed (Geringer 1991, Hennart 1998, Park \& Russo 1996), and failure rates vary from 30\% (Hennart 1998) to 50\% (Harrigan 1988, Bleeke \& Ernst 1991). 
Due to the given intriguing mix of promise and peril that IJV holds, we will go over the literature review of IJVs formation motives, partner selection, and performance assessment and how these factors relate to one another to affect the outcome and survival of the venture

\subsection{International Joint Venture Formation Motives}

IJV is the fruits of thoughtful decisions made by the company. Hence, motives must be brought to justify the creation of the venture. It is primordial for the company to understand crystal clear why it wants to enter in the venture. Strategic and economic benefits cannot be the only reason for entering an IJV, but the company should go far beyond these motives and have other motives

Theoretically, there are three approaches which help to clarify the motivation as well as the goals of IVJs:

$>$ The internalization approach which provides an economic rationale for the joint venture using the transaction cost paradigm.

$>$ The strategic behavior approach which focuses more on a theory of motivation driven by competitive positioning and the impact of such positioning on profitability

$>$ The third approach is derived from organizational theories and stresses the benefits of cooperative motivations and also includes organizational learning

\subsection{International Joint Venture Partner Selection Criteria}

The quest for a suitable partner is the most important step of IJV formation process; moreover, it is the key to the ultimate success of a joint enterprise. Partner selection will affect the mix of skills and resources which will be available for the ventures, and therefore it will not only affect IJV's performance, but also its ability to achieve its strategic objectives

A large number of selection criteria have been suggested in the literature, for instance, requisite skills and assets, compatibility and chemistry between partners, strategic fit and cultural fit (Child and Faulkner, 1998: 92). Although such criteria are reasonable but not clear enough to give us the fundamental criteria for venture partner selection. A significant contribution by Geringer $(1988 ; 1991)$ who gave a holistic view by classifying the unlimited range of alternative criteria that might exist in a simple two-fold typology of categories of selection criteria

The typology suggested by Geringer is based on the distinction between "task-related criteria and partner-related criteria".

\subsection{IJV Performance Assessment}

Most of the people take success and failure as an absolute, but they are actually a relative matters and should be assessed according to specific criteria/yardsticks.

The balance between financial return expected from the venture and achieving the motives and strategic goals which the venture was made upon is very important. One partner may consider financial return as the main yardstick to assess the venture performance; on the other hand the second partner may consider achieving the motives and strategic goals which the venture was made upon is the yardstick to assess the venture performance. Therefore IJV performance assessment appears in droves throughout the literature Yan, A. and B. Gray (1994a; 1996). We can deduct three distinct approaches to defining and measuring the IJV performance:

$>$ The first approach is a unidimensional measure that focuses on the financial assessment. This approach involves the appraisal of the venture on the basis of objectives indicators (e.g., profitability, sales growth) or subjective measures, such as the managerial assessment of IJV economic goal attainment.

$>$ The second approach which is also unidimensional assessment, involves assessing IJV stability, in terms of operational survival (e.g., rate of unexpected dissolution) or specific signs of instability (e.g., unplanned equity renegotiation) (Anderson, 1990).

$>$ The last approach which emerged in response to the criticism that the unidimentional performance measures have received, it assesses diverse IJV performance facets via managers' perceptual judgments by on one hand giving an overall viewpoint on satisfaction with performance of goal achievement, and on the other hand providing indications along multiple, specific outcome dimensions (Olk, 2001).

\section{Method}

3.1 Sample

The sample frame was made up of 5 Chinese car manufacturers which were selected on the basis of annual sales growth and patents (Cherry Automobile, BYD Auto, Brilliance Auto, Geely Auto, and Great Wall Motor). And Algerian Industrial Vehicles Manufacturer "SNVI"

\subsection{Instrumentation}

The study used a questionnaire survey which included an introductory note explaining the purpose of the study. The survey was divided in three sections, the first section used a five-point Likert scales questions 
"very important, important, moderately important, of little importance, unimportant" that sought to identify the main motives behind entering in an IJV. The second section used five-point Likert scales questions as well "very important, important, moderately important, of little importance, unimportant" in the aim to identify the complementary-resources needed from the IJV Partners. The last section used a closed ended question in the aim to find out which criteria are used to assess the venture success.

The questionnaire survey given to the Algerian Industrial Vehicles Manufacturer "SNVI" was in French language. We used three-point Likert scales questions "very important, moderately important, unimportant", and the questions were slightly different because Algeria will be the host country of the potential venture. Therefore motives to enter an IJV and partner selection criteria will be different from the 5 Chinese car manufacturers The study used descriptive analysis using frequencies and cross-tabulations of data were completed to summarize the variables and calculate the standardized values.

\section{Findings}

Table 3 Chinese Car Manufacturers' Motives to Enter in IJV

\begin{tabular}{|c|c|c|c|c|c|c|c|}
\hline \multicolumn{2}{|l|}{ Some JV Motives } & \multicolumn{5}{|c|}{ Ranking } & \multirow[t]{2}{*}{ Total } \\
\hline & & 1 & 2 & 3 & 4 & 5 & \\
\hline \multirow[b]{2}{*}{ 1-Enable Faster Entry to the Market } & Frequency & 0 & 0 & 1 & 4 & 0 & 5 \\
\hline & Percentage & $0 \%$ & $0 \%$ & $20 \%$ & $80 \%$ & $0 \%$ & $100 \%$ \\
\hline \multirow[t]{2}{*}{ 2-Enable Presence in New Market } & Frequency & 4 & 1 & 0 & 0 & 0 & 5 \\
\hline & Percentage & $80 \%$ & $20 \%$ & $0 \%$ & $0 \%$ & $0 \%$ & $100 \%$ \\
\hline \multirow[b]{2}{*}{ 3-Facilitate International Expansion } & Frequency & 1 & 4 & 0 & 0 & 0 & 5 \\
\hline & Percentage & $20 \%$ & $80 \%$ & $0 \%$ & $0 \%$ & $0 \%$ & $100 \%$ \\
\hline \multirow[t]{2}{*}{ 4-Overcome Regulatory Restrictions } & Frequency & 0 & 1 & 4 & 0 & 0 & 5 \\
\hline & Percentage & $0 \%$ & $20 \%$ & $80 \%$ & $0 \%$ & $0 \%$ & $100 \%$ \\
\hline
\end{tabular}

Field Study

The frequency analysis of the factor: Enable faster entry to the market revealed that $80 \%$ of the responses think of it as of little importance, while $20 \%$ think of it as moderately important

The frequency analysis of the factor: Enable presence in new market revealed that $80 \%$ of the responses think of it as very important, while $20 \%$ think of it as important

The frequency analysis of the factor: Facilitate international expansion revealed that $80 \%$ of the responses think of it as important, while $20 \%$ think of it as very important

The frequency analysis of the factor: Overcome regulatory restrictions revealed that $80 \%$ of the responses think of it as moderately important, while $20 \%$ think of it as of little importance

Table 4 Algerian Industrial Vehicles Manufacturer SNVI's Motives to Enter in IJV

\begin{tabular}{|c|c|}
\hline Some JV Motives & Rank \\
\hline 1-Maintain or Improve your Current Market Position & 1 \\
\hline & 1 \\
\hline 2-Compete more Effectively Against your Common Competitors & 2 \\
\hline 3-Share Investment Costs & 1 \\
\hline 4-Reduce Competition from Existing or Potential Chinese Competitor & 1 \\
\hline 5-Exchange Technology & 2 \\
\hline 6-economy of Scale & 3 \\
\hline 7-Product Diversification & 3 \\
\hline 8-Share Costs of R \& D & 2 \\
\hline 9-To Focus on Higher Margin Activities & 1 \\
\hline 11-A rapid Return on Investment & 1 \\
\hline 12-Exchange or Acquire Patents & 3 \\
\hline
\end{tabular}

Field Study

Table 4 shows that "S.N.V.I" Algerian Industrial Vehicles manufacturer considers that improving the current market position, exchange technology, a rapid return on investment, reduce competition from existing or potential Chinese competitors, compete more effectively against the common competitors, and Spreading the risk of a major project on more than one company as very important Motives to enter in IJV.

Algerian Industrial Vehicles manufacturer considers that: sharing investment costs, reaching economy of scale, and focus on higher margin activities as important factors to enter in an IJV

Algerian Industrial Vehicles manufacturer considers that product diversification, share costs of R \& D, exchange or acquire patents are unimportant motives to enter in an IJV. 
Table 5 Chinese Car Manufacturers' Expectations to Get Complementary-Resource from IJV Partners

\begin{tabular}{|c|c|c|c|c|c|c|c|}
\hline \multirow{2}{*}{\multicolumn{2}{|c|}{$\begin{array}{l}\text { Expected Complementary Resource From JV } \\
\text { Partner } \\
\end{array}$}} & \multicolumn{5}{|c|}{ Ranking } & \multirow{3}{*}{$\begin{array}{c}\text { Total } \\
5 \\
\end{array}$} \\
\hline & & \multirow{2}{*}{$\begin{array}{l}1 \\
5\end{array}$} & \multirow{2}{*}{$\begin{array}{ll}2 \\
0 \\
\end{array}$} & \multirow{2}{*}{$\begin{array}{l}3 \\
0\end{array}$} & \multirow{2}{*}{$\begin{array}{l}4 \\
0\end{array}$} & \multirow{2}{*}{$\frac{5}{0}$} & \\
\hline & Frequency & & & & & & \\
\hline 1-Materials/ Natural Resources & Percentage & $100 \%$ & $0 \%$ & $0 \%$ & $0 \%$ & $0 \%$ & $100 \%$ \\
\hline \multirow[t]{2}{*}{ 2-Technology } & Frequency & 5 & 0 & 0 & 0 & 0 & 5 \\
\hline & Percentage & $100 \%$ & $0 \%$ & $0 \%$ & $0 \%$ & $0 \%$ & $100 \%$ \\
\hline \multirow[t]{2}{*}{ 3-Labor } & Frequency & 0 & 0 & 0 & 4 & 1 & 5 \\
\hline & Percentage & $20 \%$ & $80 \%$ & $0 \%$ & $80 \%$ & $20 \%$ & $100 \%$ \\
\hline \multirow[t]{2}{*}{ 4-Capital/Finance } & Frequency & 5 & 0 & 0 & 0 & 0 & 5 \\
\hline & Percentage & $100 \%$ & $0 \%$ & $0 \%$ & $0 \%$ & $0 \%$ & $100 \%$ \\
\hline \multirow[t]{2}{*}{ 5-Distribution Channels } & Frequency & 0 & 2 & 0 & 3 & 0 & 5 \\
\hline & Percentage & $0 \%$ & $40 \%$ & $0 \%$ & $60 \%$ & $0 \%$ & $100 \%$ \\
\hline \multirow[t]{2}{*}{ 6-The Product } & Frequency & 0 & 4 & 1 & 0 & 0 & 5 \\
\hline & Percentage & $0 \%$ & $80 \%$ & $20 \%$ & $0 \%$ & $0 \%$ & $100 \%$ \\
\hline \multirow{2}{*}{$\begin{array}{c}\text { 7-Knowledge of Production } \\
\text { Processes }\end{array}$} & Frequency & 0 & 1 & 2 & 2 & 0 & 5 \\
\hline & Percentage & $0 \%$ & $20 \%$ & $40 \%$ & $40 \%$ & $0 \%$ & $100 \%$ \\
\hline \multirow[t]{2}{*}{ 8-Production Capacity } & Frequency & 0 & 0 & 4 & 1 & 0 & 5 \\
\hline & Percentage & $0 \%$ & $0 \%$ & $80 \%$ & $20 \%$ & $0 \%$ & $100 \%$ \\
\hline \multirow[t]{2}{*}{ 9-Regulatory Permit } & Frequency & 0 & 2 & 3 & 0 & 0 & 5 \\
\hline & Percentage & $0 \%$ & $40 \%$ & $60 \%$ & $0 \%$ & $0 \%$ & $100 \%$ \\
\hline \multirow[t]{2}{*}{ 10-Local Brand Names } & Frequency & 0 & 0 & 2 & 3 & 0 & 5 \\
\hline & Percentage & $0 \%$ & $0 \%$ & $40 \%$ & $60 \%$ & $0 \%$ & $100 \%$ \\
\hline \multirow{2}{*}{$\begin{array}{l}\text { 11-Link with Major Buyers \& } \\
\text { Suppliers } \\
\end{array}$} & Frequency & 0 & 2 & 1 & 2 & 0 & 5 \\
\hline & Percentage & $0 \%$ & $40 \%$ & $20 \%$ & $40 \%$ & $0 \%$ & $100 \%$ \\
\hline \multirow{2}{*}{$\begin{array}{l}\text { 12-Knowledge of the Local } \\
\text { Market }\end{array}$} & Frequency & 0 & 0 & 0 & 1 & 4 & 5 \\
\hline & Percentage & $0 \%$ & $0 \%$ & $0 \%$ & $20 \%$ & $80 \%$ & $100 \%$ \\
\hline \multirow{2}{*}{$\begin{array}{l}\text { 13-Knowledge of the Local } \\
\text { Culture }\end{array}$} & Frequency & 0 & 0 & 0 & 0 & 5 & 5 \\
\hline & Percentage & $0 \%$ & $0 \%$ & $0 \%$ & $0 \%$ & $100 \%$ & $100 \%$ \\
\hline \multirow{2}{*}{$\begin{array}{l}\text { 14-To Cope with Government } \\
\text { \& Administration Bodies }\end{array}$} & Frequency & 0 & 4 & 1 & 0 & 0 & 5 \\
\hline & Percentage & $0 \%$ & $80 \%$ & $20 \%$ & $0 \%$ & $0 \%$ & $100 \%$ \\
\hline
\end{tabular}

Field Study

The frequency analysis of the factor: materials/ natural resources revealed that $100 \%$ of the responses think of it as very important

The frequency analysis of the factor: technology revealed that $100 \%$ of the responses think of it as very important

The frequency analysis of the factor: labor revealed that $80 \%$ of the responses think of it as of little importance, while $20 \%$ think of it as unimportant

The frequency analysis of the factor: capital/finance revealed that $100 \%$ of the responses think of it as very important

The frequency analysis of the factor: distribution channels revealed that $40 \%$ of the responses think of it as important, while $60 \%$ think of it as moderately important

The frequency analysis of the factor: the product revealed that $80 \%$ of the responses think of it as important, while $20 \%$ think of it as moderately important

The frequency analysis of the factor: knowledge of production processes revealed that $20 \%$ of the responses think of it as important, while $40 \%$ think of it as moderately important, and $40 \%$ think of it as of little importance

The frequency analysis of the factor: production capacity revealed that $80 \%$ of the responses think of it as moderately important, while $20 \%$ think of it as of little importance

The frequency analysis of the factor: regulatory permit revealed that $40 \%$ of the responses think of it as important, while $60 \%$ think of it as moderately important

The frequency analysis of the factor: local brand names revealed that $40 \%$ of the responses think of it as moderately important, while $60 \%$ think of it as of little importance

The frequency analysis of the factor: link with major buyers and suppliers revealed that $40 \%$ of the responses think of it as important, while $20 \%$ think of it as moderately important, and $40 \%$ think of it as of little importance.

The frequency analysis of the factor: knowledge of the local market revealed that $20 \%$ of the responses think of it as of little importance, while $80 \%$ think of it as unimportant

The frequency analysis of the factor: knowledge of the local culture revealed that $100 \%$ of the responses think of it as unimportant 
The frequency analysis of the factor: to cope with government and administration bodies revealed that $80 \%$ of the responses think of it as important, while $20 \%$ think of it as moderately important

Table 6 Algeria Industrial Vehicles Manufacturer's Expectations to Get Complementary Resource from IJV Partner

\begin{tabular}{|c|c|}
\hline Expected Complementary Resource From JV Partner & Rank \\
\hline 1-Materials/ Natural Resources & 1 \\
\hline 2-Technology & 3 \\
\hline 3-Labour & 1 \\
\hline 4-Capital / Finance & 2 \\
\hline 5- improve Distribution Channels & 2 \\
\hline 6- Use of the Partner Brand Name & 1 \\
\hline 7-Knowledge of Production Processes & 2 \\
\hline 8-Production Capacity & 3 \\
\hline
\end{tabular}

Field Study

Table 6 shows that Algeria Industrial Vehicles Manufacturer considers that: knowledge of production processes, technology, and capital/finance as very important complementary resources which is expecting to get from its venture partner.

Algeria Industrial Vehicles Manufacturer considers that: materials/ natural resources, improving distribution channels, production capacity, and use partner' brand name as important complementary resources which is seeking to get from its venture partner.

Finally the Algeria Industrial Vehicles Manufacturer considers that: labor, improving the link with major buyers $\&$ suppliers as unimportant complimentary resources.

Regarding IJV performance assessment, the 5 Chinese car manufacturers consider that the venture should be mainly assessed by how far the venture formation motives are achieved not by its financial return. By contrast, S.N.V.I Algerian Industrial Vehicles manufacturer consider that the venture financial return should be taken as the main yardstick to assess its success, and in less degree the achievements of the motives which the venture was made upon

\section{Discussion \& Conclusion}

This study revealed that there are disparities in the motives for establishing an IJV in car manufacturing between Algeria and China. These disparities can be explained by the type of this IJV, in which Algeria will be the host country of this venture, therefore, the local \& foreign partners will have different motives. Nonetheless, this IJV between Chinese and Algerian would be able to achieve each partner motives. On one hand, the venture can facilitate the international expansion \& cost reduction for the Chinese car manufacturers by establishing an internal structure to serve the Algerian market rather than dealing with market intermediaries. Moreover, doing a venture with local partner will help to overcome regulatory restrictions and enable faster entry to the market, especially with Algeria terrible Business climate. On the other hand, the venture can help the Algerian to achieve some motives. For instance the Chinese partners could improve the Algerian partner current market position by competing more effectively against common competitors, spreading the risks of major projects on more than one company, and exchange technologies.

Concerning partner selection, the study revealed also that both partners are expecting similar complementary resources from the other venture partner which are mainly: capital/finance \& technology. By contrast, the Algerian partner can provide some complementary resources which are expected by the Chinese partners, like cheap materials \& natural resource, knowledge on how to deal with government and administration bodies, distribution channels. On the other hand, the Chinese partners can provide some complementary resources which are expected by the Algerian partner, like knowledge of production processes and advanced technology.

The research has many limitations, for instance selecting just 5 Chinese car manufacturers out of huge numbers may not give a holistic image of the whole Chinese car manufacturers. Nonetheless, not all the Chinese car manufacturers have the clout and means to compete globally. Second limitation could be the finite numbers of options given in the questionnaire survey concerning motives of establishing an IJV, and complimentary resources as well. Although the questionnaire survey showed that the Chinese car manufacturers do not give that importance to the knowledge of the local culture and local market. Therefore, this point could be a starting point for new research about the effect of cultural background differences on the performance \& survival of potential IJV between Algeria \& China 


\section{References}

[1] Pan, Y. \& Chi, P.S.K. 1999. Financial performance and survival of multinational corporations in China. Strategic Management Journal, 20(4): 359-374

[2] Shenkar, O.\& Nyaw, M-K. 1994. How to run a successful joint venture in China. Advances in Chinese Industrial Studies, 4: 273283

[3] Geringer, J.M \& Hebert, L. 1991. Measuring performance of international joint ventures. Journal of International Business Studies, 22(2): 249-264.

[4] Hennart, J.-F. 1998. The impact if joint venture status on the longevity of Japanese stakes in U.S. manufacturing affiliates. Organization Science, 9(3): 382.

[5] Parks, S.H.\& Russo, M.V.1996. When competition eclipses cooperation: and event history analysis of joint venture failure. IPA Review, 49(1): 875-890

[6] Harrigan, K.R.1988a. Joint ventures and competitive strategy. Strategic Management Journal, 9(2): $141-148$.

[7] Bleeke, J. \& Ernst, D. 1991. The way to win in cross-border alliances. Harvard Business Review, 69(6): 127-135.

[8] Child, J. \& Faulkner, D. 1998. Strategies of Cooperation: Managing Alliances, Networks, and Joint Ventures. New York, NY: Oxford University Press.

[9] Geringer, J.M. 1988. Joint Venture Partner Selection: Strategies for Developed Countries. Westport, CT: Quorum Books.

[10] Yan, A. and B. Gray (1996), 'Linking management control and inter-partner relationships with performance in US-Chinese joint ventures', in J. Child and Y. Lu (eds), Management Issues in China: International Enterprises, London: Rutledge, pp. 106-27

[11] Anderson, E. (1990), 'two firms, one frontier: On assessing joint venture performance'. Sloan Management Review, 31(2), 19-30

[12] Olk, P. (2001), 'Measuring strategic alliance performance: A review and commentary on what have we used and how to proceed', paper given at the Conference on 'Cooperative Strategies and Alliances: What We Know 15 Years Later', Lausanne, Switzerland, 23-25 June. 